\title{
MEMBANGUN APLIKASI PELAYANAN JASA STEAM MOTOR DAN MOBIL PADA AFRA SNOW WASH
}

\author{
Abdul Kholikussifa', Aswin Fitriansyah², Muhammad Irsan ${ }^{3}$ \\ ${ }^{1,2,3}$ Teknik Informatika, Fakultas Teknik dan Ilmu Komputer, Universitas Indraprasta PGRI Jakarta \\ Jalan Raya Tengah No 80, Kelurahan Gedong, Pasar Rebo, Jakarta Timur \\ 1.abduliik12@gmail.com, 2 aswin.fitriansyah@gmail.com, $\underline{3}$ atstairway@gmail.com
}

\begin{abstract}
ABSTRAK
Afra Snow Wash merupakan perusahaan yang bergerak dibidang jasa, khususnya pada jasa pencucian kendaraan bermotor. Afra Snow Wash memiliki visi untuk memberikan pelayanan dengan profesionalitas yang dilandasi oleh kepuasan pelanggan. Permasalahan yang terdapat pada Afra Snow Wash adalah sering terjadinya kehilangan berkas pada saat pelaporan bulanan kepada pimpinan diakibatkan human error dan pencatatan data pelanggan dan pembuatan nota transaksinya masih dicatat pada lembaran kertas menggunakan tulisan tangan dan juga ada disimpan pada map (stell helder). Tujuan merancang suatu sistem informasi pelayanan jasa steam motor dan mobil ini dengan tujuan untuk memudahkan admin dalam memproses pengolahan data yang ada saat ini. Perangkat aplikasi yang telah dibuat dengan bahasa pemrograman Java NetBeans 8.0.2 dan penyimpanan data pada database MySQL dapat memberikan kelancaran dalam proses menginput dan penyimpanan data-data serta laporan-laporan yang diberikan kepada pemilik steam motor dan mobil Afra Snow Wash. Metode penelitian yang digunakan dengan metode Research and Development yang dapat mampu menyelesaikan permasalahan. Hasil dari penelitian ini merancang aplikasi yang dapat memproses data pelanggan serta pelayanan jasa steam motor dan mobil pada Afra Snow Wash secara terkomputerisasi yang membantu admin sehingga menghasilkan laporan yang tersimpan dengan baik dan memberikan hasil secara cepat dan akurat.
\end{abstract}

Kata Kunci: Aplikasi, Pelayanan, Steam, Desktop

\begin{abstract}
Afra Snow Wash is a company engaged in services, especially in motor vehicle washing services. Afra Snow Wash has a vision to provide services with professionalism based on customer satisfaction. The problem with Afra Snow Wash is the frequent occurrence of file loss at the time of monthly reporting to the leadership due to human error and recording customer data and the making of transaction notes is still recorded on sheets of paper using handwriting and is also stored on a map (stell helder). The purpose of designing a service information system for steam motorbikes and cars is to make it easier for admins to process existing data processing. Application devices that have been created with the Java NetBeans 8.0.2 programming language and data storage in the MySQL database can provide a smooth process of inputting and storing data and reports provided to owners of steam motors and Afra Snow Wash cars. The research method used is the Research and Development method that can solve problems. The results of this study design an application that can process customer data and service steam motorbikes and cars at Afra Snow Wash computerized which helps admins to produce reports that are stored properly and provide results quickly and accurately.
\end{abstract}

Key Word: Application, Service, Steam, Desktop

\section{PENDAHULUAN}

Sistem Informasi merupakan fondasi yang membangun seluruh jenis kegiatan transaksi. Khususnya dalam bidang bisnis penyedia jasa, sistem informasi digunakan dalam memonitoring atau mengawasi seluruh kegiatan transaksi. Dengan begitu, kualitas pemberian pelayanan jasa kepada Pelanggan menjadi lebih berkualitas. Selain dari kualitas pemberian pelayanan jasanya itu sendiri, Sistem informasi mampu menjadi media bagi perusahaan jasa untuk memberikan pelayanan yang lebih baik. Misalnya sebagai sarana promosi, sarana informasi, sarana pelayanan, dan banyak hal lain lagi yang dapat diperoleh dari kegunaan sistem informasi (Muttaqin \& Permana, 2020).

Afra Snow Wash merupakan perusahaan yang bergerak dibidang jasa, khususnya pada jasa pencucian kendaraan bermotor. Afra Snow Wash memiliki visi untuk memberikan pelayanan 
dengan profesionalitas yang dilandasi oleh kepuasan pelanggan. Pelayanan di tempat pencucian motor dan mobil pada Afra Snow Wash ini masih menggunakan sistem yang manual (Shadiq \& Putra, 2019). Terlihat dari pendataan pelanggan, dan juga pembuatan nota transaksinya masih dicatat pada lembaran kertas menggunakan tulisan tangan dan juga ada disimpan pada map (stell helder). Hal ini menimbulkan pemrosesan data informasi menjadi tidak efisien (Anis et al., 2020).

Jasa pelayanan merupakan setiap tindakan atau kegiatan yang dapat ditawarkan oleh satu pihak kepada pihak lain, pada dasarnya tidak berwujud dan tidak mengakibatkan kepemilikan apapun (Kotler, 2016).

Perancangan sistem informasi yang akan diterapkan dapat memudahkan dalam pengolahan data sehingga mendapatkan manfaat yaitu membantu pengolahan data secara terkomputerisasi untuk memudahkan dan mempercepat proses transaksi, memudahkan pencarian data, memudahkan pembuatan laporan dan meminimalisir kesalahan proses pencatatatn transaksi (Christian, Rizal, Alam, \& Amir, 2019).

Dengan permasalahan tersebut, perlu ada nya suatu sistem yang terkomputerisasi dalam penyelesaiannya. Sistem adalah sekelompok unsur yang erat hubungannya satu dengan yang lain, yang berfungsi bersama-sama untuk mencapai tujuan (Sutabri, 2012). Sistem merupakan suatu kumpulan dari komponenkomponen yang membentuk satu kesatuan (Tyoso, 2016). Pembangunan sistem adalah sekumpulan aktivitas yang menggambarkan secara rinci bagaimana sistem akan berjalan. Hal itu bertujuan untuk menghasilkan produk perangkat lunak yang sesuai dengan kebutuhan user (Satzinger, J. W., Jackson, R. B., Burd, n.d.).

Diharapkan dengan adanya suatu sistem informasi dapat menangani permasalahan yang ada di perusahaan tersebut. Sistem adalah setiap sesuatu terdiri dari obyek-obyek, atau unsur-unsur, atau komponen-komponen yang bertata kaitan dan bertata hubungan satu sama lain, sedemikian rupa sehingga unsur-unsur tersebut merupakan satu kesatuan pemrosesan atau pengolahan yang tertentu. (Prasojo, 2011)

Aplikasi ini dapat memudahkan pekerjaan Admin dalam melaksanakan pembuatan laporan dan dapat memudahkan karyawan dalam memberikan pelayanan jasa yang maksimal serta memudahkan dalam penginputan data serta pencarian data yang ada pada Afra Snow Wash.

\section{METODE PENELITIAN}

Peneliti menggunakan metode Research and Development dalam penyelesaian penelitian ini. (Sugiyono, 2016). Dalam pelaksanaan R\&D, ada beberapa metode yang digunakan yaitu metode deskriptif, evaluatif dan eksperimental. Metode penelitian deskriptif digunakan dalam penelitian awal untuk menghimpun data tentang kondisi yang ada yaitu penulis membutuhkan data-data yang dapat menunjang tercipta nya suatu sistem aplikasi pelayanan jasa steam motor dan mobil seperti data pelanggan, data petugas, data steam motor dan data steam mobil terdahulu yang masih tersimpan secara manual didalam buku besar. Metode evaluatif digunakan untuk mengevaluasi proses ujicoba pengembangan suatu produk, dalam proses ini penulis melakukan ujicoba terhadap suatu sistem yang telah dirancang agar tidak ada terjadi kesalahan dalam proses penginputan data serta pelaporan bulanan kepada pimpinan. Dan metode eksperimen digunakan untuk menguji keampuhan dari produk yang dihasilkan, dalam proses yang terakhir ini perlu dilakukan pengujian akhir yang diharapkan bahwa sistem yang dirancang oleh penulis dapat berjalan dengan baik dan sesuai dengan kebutuhan dan terfokus pada proses pendataan pelayanan jasa steam motor dan mobil pada Afra Snow Wash (Putra, 2011).

\section{HASIL DAN PEMBAHASAN Analisa Permasalahan}

Analisis permasalahan yang dapat peneliti simpulkan dari hasil penelitian yang dilakukan di Afra Snow Wash adalah bahwa, instansi ini termasuk salah satu instansi yang belum memiliki sistem informasi berbasis komputerisasi dalam pengolahan data pelayanan jasa steam motor dan mobil serta managemen data pelanggan, sehingga dirasakan masih sangat membutuhkan sistem yang mampu dan memberikan kemudahan bagi bagian 
yang terkait dalam sistem pengolahan data pelayanan jasa steam motor dan mobil. Ada beberapa permasalahan yang dimiliki oleh pihak instansi antara lain, pelayanan jasa pencucian kendaraan yang masih dilakukan pencatatan secara manual dengan menggunakan berkas sehingga menyulitkan karyawan ketika akan melakukan pencarian data ataupun pengarsipan data. Pencatatan pelayanan jasa yang berjalan belum maksimal karena penggunaan berkas sebagai sarana pencatatan pelayanan jasa. Dalam proses pengarsipan pelayanan jasa masih menggunakan pencatatan buku besar sehingga petugas sering kesulitan mencari data pelayanan jasa pencucian kendaraan.

Dalam sistem pelayanan jasa pencucian kendaraan yang berjalan, sering terjadi kehilangan data yaitu tidak ditemui berkas penunjang untuk membuktikan bahwa pelanggan sudah melakukan pembayaran administrasi. Pelaporan pelayanan jasa yang sering terlambat karena banyaknya data yang harus di input dan disetorkan oleh karyawan yang bersangkutan karena masih mencatat dengan menggunakan worksheet. Kendala dari setiap tugas-tugas karyawan adalah pada saat mengerjakan tugas-tugas tersebut masih mebutuhkan waktu yang cukup lama.

\section{Alternatif Penyelesaian Masalah}

Alternatif penyelesaian masalah yang peneliti usulkan adalah dengan membuat sebuah aplikasi sistem pelayanan jasa pencucian kendaraan dan managemen data pelanggan dengan menggunakan bahasa pemrograman Java dan penyimpanan datadata pada media database. Dengan adanya aplikasi ini diharapkan mampu memberikan kontribusi yang positif bagi kemajuan dalam pengolahan data-data pelayanan jasa pencucian kendaraan. Proses pencarian data tidak lagi membutuhkan waktu yang lama karena data-data pelayanan jasa pencucian kendaraan yang ada sudah tersimpan pada media database. Dengan usulan ini diharapkan permasalahan pada pengolahan data-data pelayanan jasa pencucian kendaraan dapat tertangani dengan cepat dan akurat.

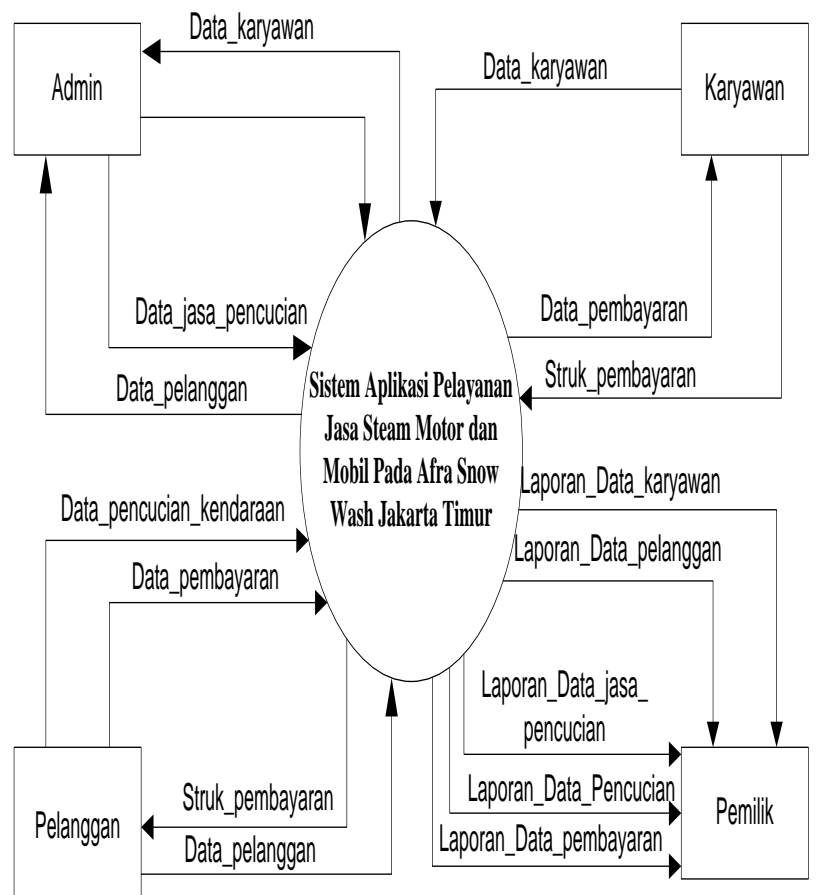

Gambar 1. Diagram Konteks

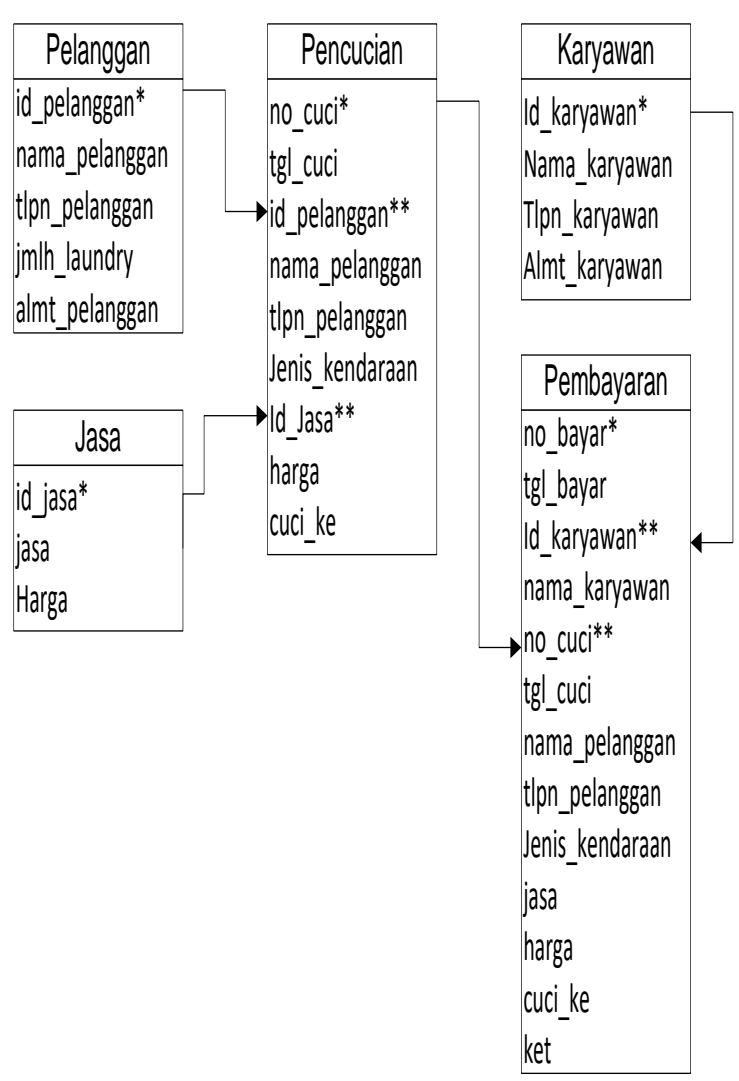

Gambar 2. Normalisasi 


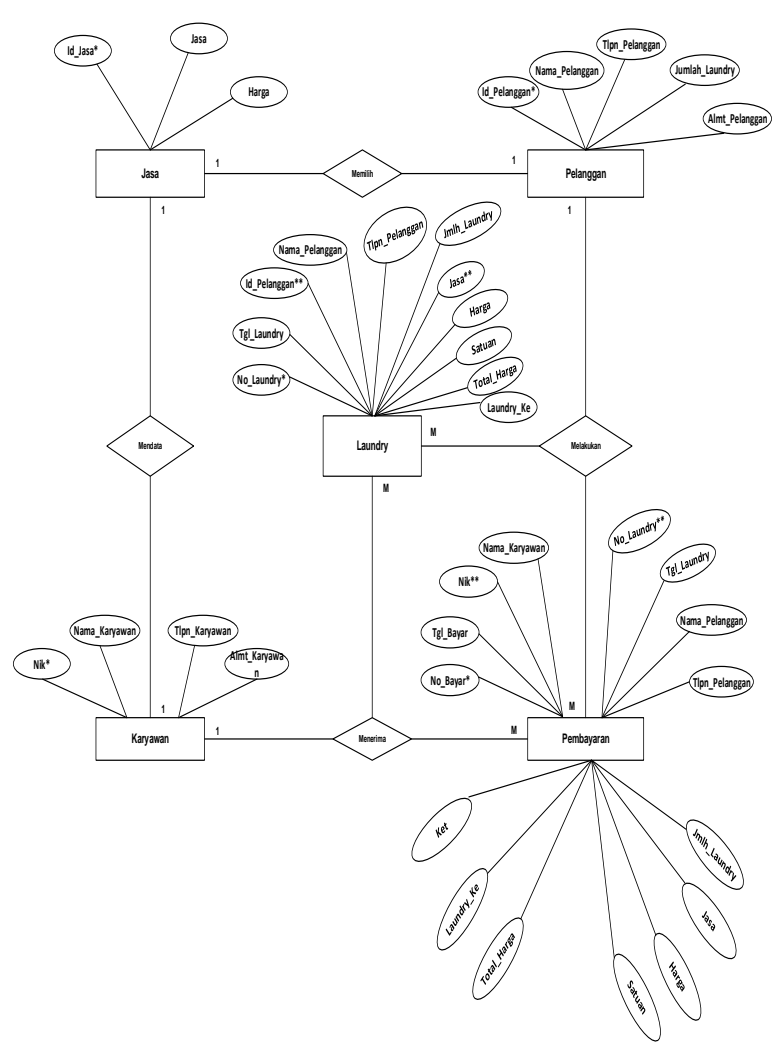

Gambar 3. ERD (Entity Relationship Diagram)

Berikut adalah tampilan layar dan hasil pengujian pada software program yang telah di buat dengan bahasa pemrograman Java.

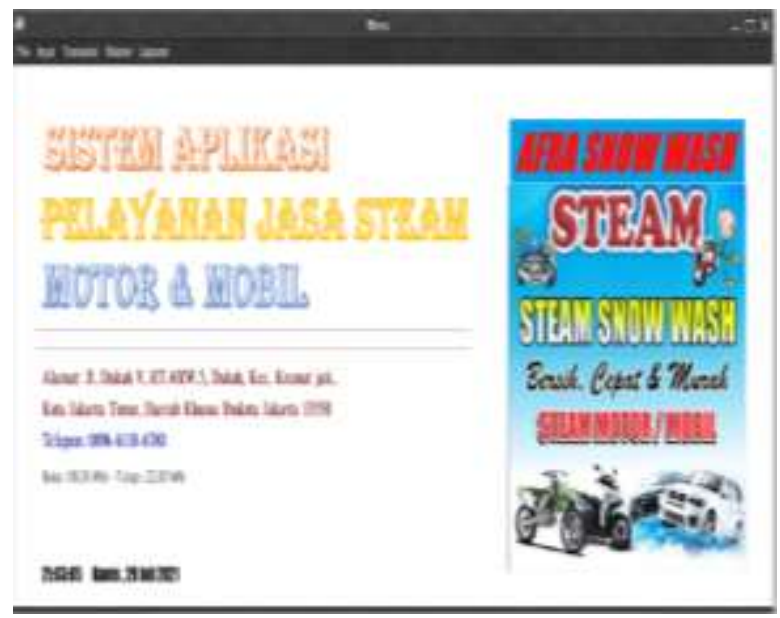

Gambar 4. Form Menu Utama

Layar di atas menampilkan tampilan Menu Utama pada Sisten Aplikasi Pelayanan Jasa Steam Motor dan Mobil Pada Afra Snow Wash. Pada layar utama tersedia menu bar yang terdiri dari master data yang digunakan untuk memasukkan data yang berkaitan dengan data karyawan, data jasa cuci, data transaksi cuci, data pembayaran dan laporan-laporan serta nota transaksi cuci dan nota pembayaran.

sis

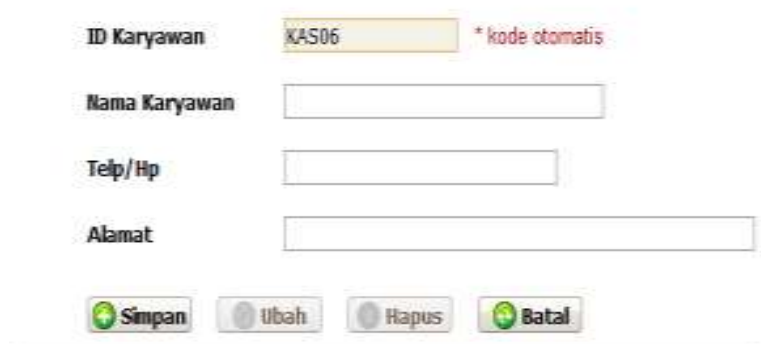

\begin{tabular}{|c|c|c|c|}
\hline DKaryawan & Nama Karyaman & Telp & Alamat \\
\hline KASO1 & Usman Hasannudin & 08172617711 & Jakata Timur \\
\hline KASA2 & Baharudin & 0819719911 & Jakata Timur \\
\hline KASP3 & Junaed: & 081289891112 & Condet \\
\hline KASM & Willy & 0878978483222 & Kalibata \\
\hline KASU5 & Hery & 089663673333 & Condet \\
\hline
\end{tabular}

Gambar 5. Form Data Karyawan

Layar di atas menampilkan tampilan form data karyawan. Pada layar form data karyawan untuk meng-input data karyawan yang terdiri dari Kode Karyawan, Nama Karyawan, No Telp dan Alamat.

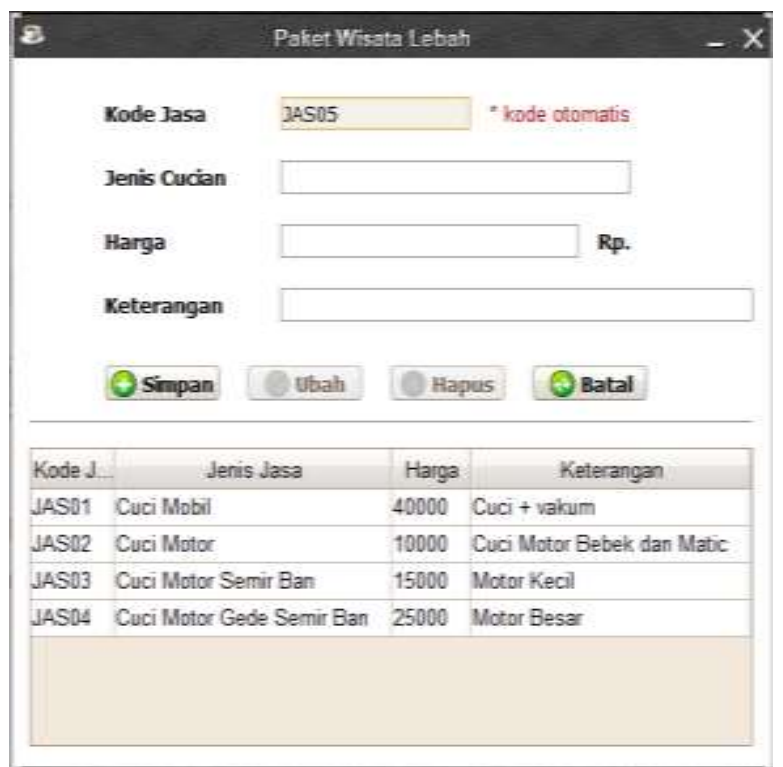

Gambar 6. Form Data Jasa Cuci

Layar di atas menampilkan tampilan form data jasa cuci. Pada layar form data jasa cuci untuk 
meng-input data jasa cuci yang terdiri dari Kode Jasa, Jenis Cucian, dan Harga Jasa.

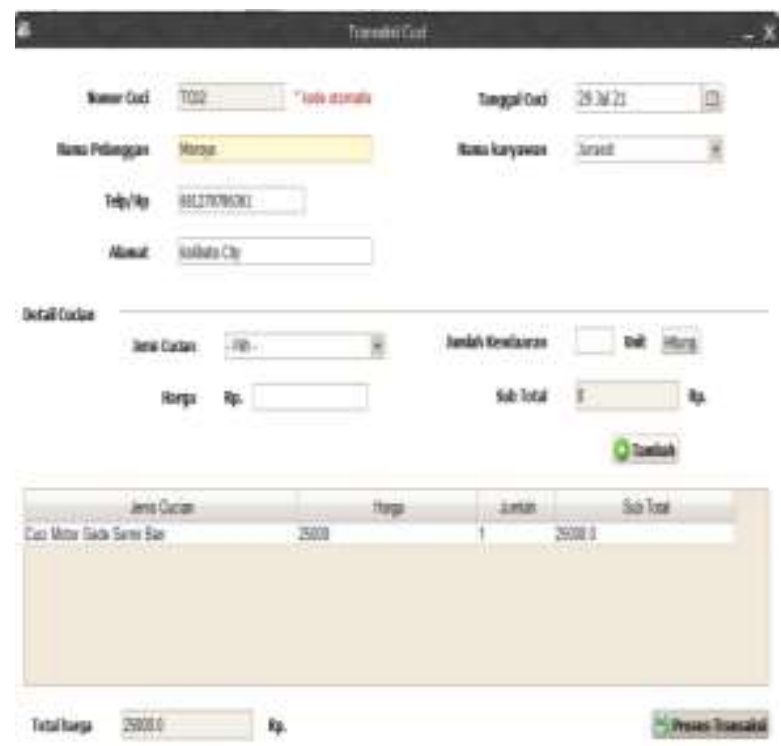

Gambar 7. Data Form Data Transaksi

Layar di atas menampilkan tampilan form data transaksi. Pada layar form data transaksi untuk meng-input data transaksi yang terdiri dari Nomor Cuci, Nama Pelanggan, No Telp, Alamat, Tgl Cuci, Tgl Pengambilan, Nama Karyawan, Jenis Cucian, Harga, Berat Cucian, Sub Total, dan Total Harga.

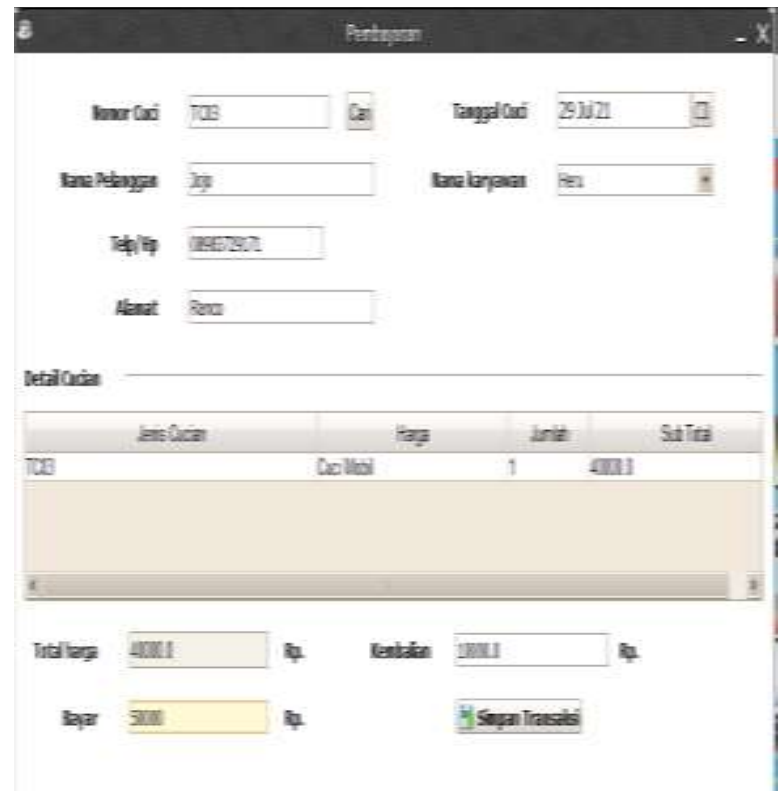

Gambar 8. Form Data Pembayaran

Layar di atas menampilkan tampilan form data pembayaran. Pada layar form data pembayaran untuk meng-input data pembayaran yang terdiri dari Nomor Cuci, Nama Pelanggan, No Telp, Alamat, Tgl Cuci, Tgl Pengambilan, Nama Karyawan, Total Harga, Bayar, dan Kembalian.

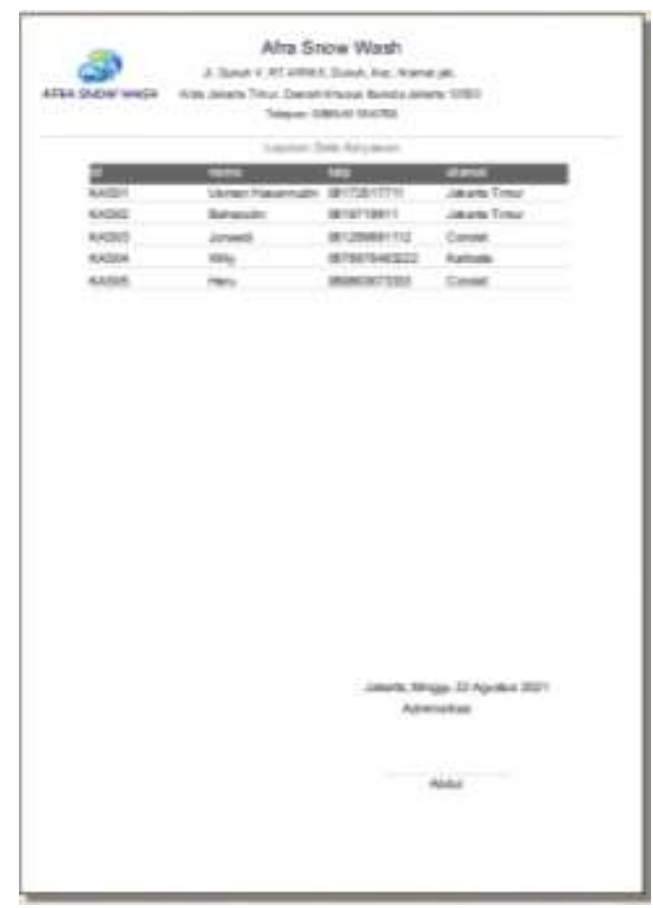

Gambar 9. Laporan Data Karyawan

Layar di atas menampilkan tampilan form laporan data karyawan. Pada layar form data karyawan digunakan untuk mengecek laporan data karyawan terdiri Kode Karyawan, Nama Karyawan, No Telp dan Alamat.

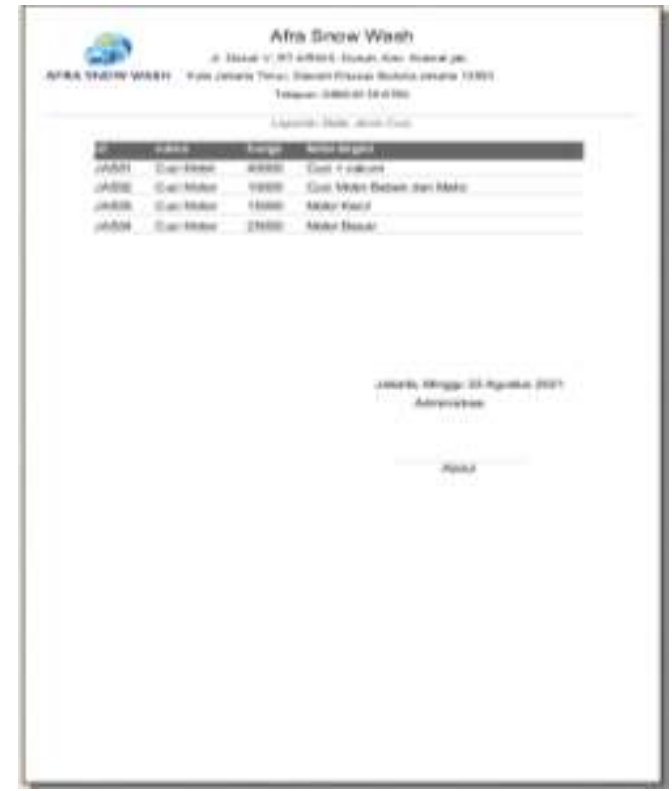

Gambar 10. Laporan Data Jasa Cuci

637 | Membangun Aplikasi Pelayanan Jasa Steam Motor dan Mobil pada Afra Snow Wash 
Layar di atas menampilkan tampilan form laporan data jasa cuci. Pada layar form data jasa cuci digunakan untuk mengecek laporan data jasa cuci terdiri ID Jasa Cuci, Nama, Harga dan Keterangan.

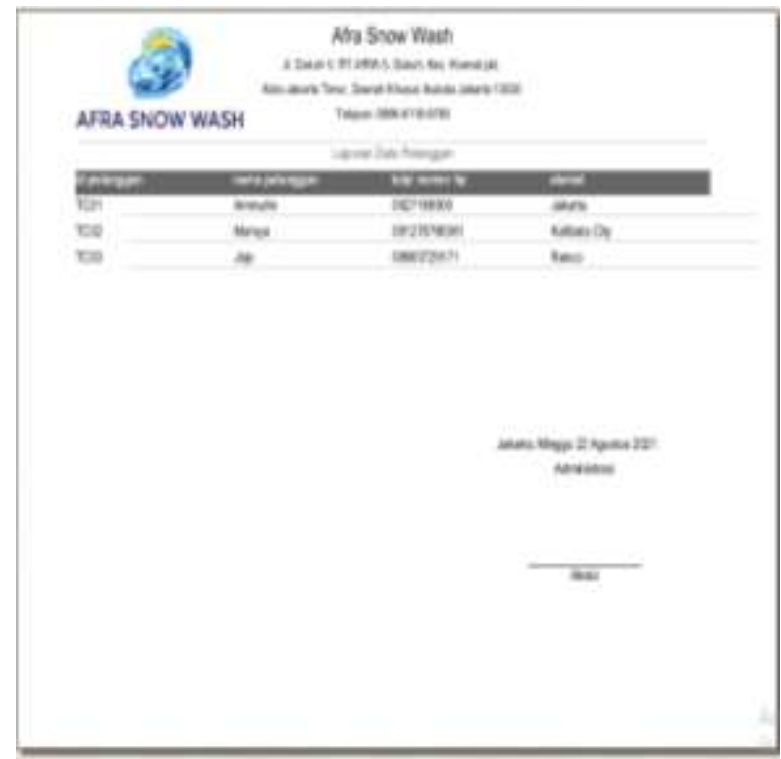

Gambar 11. Laporan Data Pelanggan

Layar di atas menampilkan tampilan form laporan data pelanggan. Pada layar form data pelanggan digunakan untuk mengecek laporan data pelanggan terdiri ID Pelanggan, Nama Pelanggan, No Telp dan Alamat.

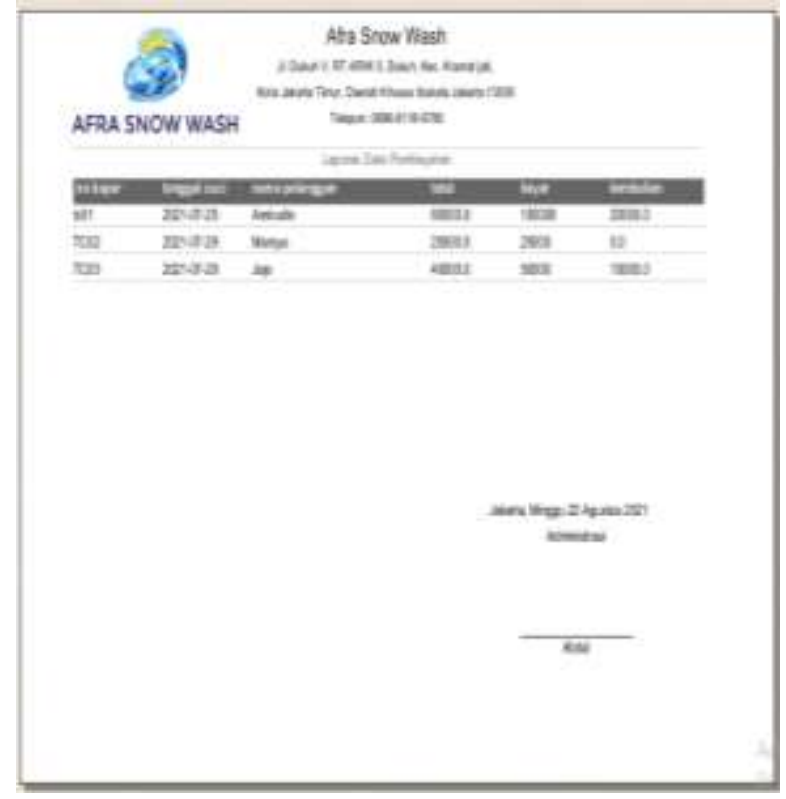

Gambar 12. Laporan Data Pembayaran
Layar di atas menampilkan tampilan form laporan data penjualan. Pada layar form data penjualan digunakan untuk mengecek laporan data penjualan terdiri No Penjualan, Tgl Penjualan, Kode Barang, Jumlah dan Sub Total.

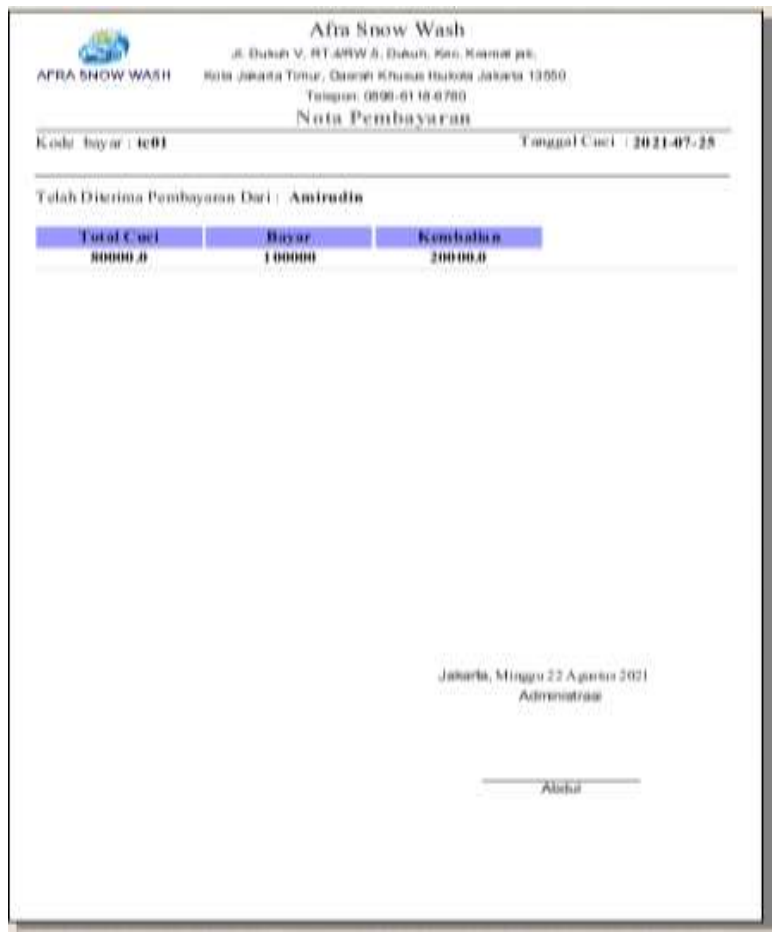

Gambar 13. Nota Pembayaran

Layar di atas menampilkan tampilan nota transaksi. Pada layar nota transaksi terdiri Kode Bayar, Tgl Cuci, Total Cuci, Bayar dan Kembalian.

\section{SIMPULAN DAN SARAN}

Sistem aplikasi pelayanan jasa steam motor dan mobil yang sedang berjalan di Afra Snow Wash masih sederhana, pencatatan data-data pelayanan jasa pencucian kendaraan masih dilakukan secara manual dan belum efektif dalam mampu mengatasi masalah-masalah yang masih sering terjadi. Sistem aplikasi pelayanan jasa steam motor dan mobil diharapkan bisa membantu mempermudah Pemilik dan bagian yang terkait dalam pengolahan data dan pencarian data yaitu data pelanggan, data jasa, data pencucian kendaraan, dan data pembayaran serta membantu mempermudah dalam penyusunan laporan setiap akhir bulan. 
Sarannya adalah sebaiknya sistem ini masih perlu diperbaharui dengan melakukan proses pembagian pelayanan jasa steam motor dan mobil secara keseluruhan dari setiap pelanggan.

\section{DAFTAR PUSTAKA}

Anis, M., Hilmi, A., Suheryadi, A., Ismantohadi, E., Hermawan, W., Indramayu, P. N., \& Indramayu, K. (2020). Pengembangan Jasa Cuci Kendaraan Panggilan Terintegrasi Dengan Aplikasi Web dan Mobile. IKRAITH-ABDIMAS, 3(3), 155-163.

Christian, A., Rizal, K., Alam, N., \& Amir. (2019). Perancangan Sistem Informasi Jasa Cuci Mobil dan Motor. Inti Nusa Mandiri, 14(1), 65-70.

Kotler, P. and K. L. K. (2016). Marketing Management, 15th Edition. New Jersey: Pearson Education.

Muttaqin, M. F., \& Permana, S. D. H. (2020). Sistem Informasi Steam Mobil Dan Motor. SINGULARITY: Jurnal Desain Dan Industri Kreatif, 01(01), 19-25. https://doi.org/10.31326/jsing.v1i1.654

Prasojo, M. (2011). Pengantar Sistem Informasi Manajemen. bandung: CV. Remadja Karya.

Putra, N. (2011). Research and Development, Penelitian dan Pengembangan: Suatu Pengantar. Jakarta: PT Raja Grafindo Persada.

Satzinger, J. W., Jackson, R. B., Burd, S. D. (n.d.). System Analysis and Design in A Changing World. USA: Cengage Learning.

Shadiq, J., \& Putra, M. Y. (2019). Perancangan Sistem Informasi Pelayanan Pembayaran Cuci Steam Kendaraan Bermotor. Informatics For Educators And Professionals, 3(2), 205-214.

Sugiyono. (2016). Metode Penelitian Kuantitatif, Kualitatif dan $R \& D$. Bandung: PT Alfabet.

Sutabri, T. (2012). Analisis Sistem Informasi. Yogyakarta: Andi.

Tyoso, J. S. P. (2016). Sistem Informasi Manajemen. Yogyakarta: DeePublish. 